\title{
Sistem Pemerintahan Indonesia: Pendekatan Teori dan Praktik
}

\author{
Ahmad Yani \\ Padjadjaran University, Indonesia \\ a.ahmadyani287@gmail.com
}

\begin{abstract}
Indonesia's presidential system prerequisites the separation of powers of executive, legislative and judiciary as it is based on checks and balances. It is stated in the Indonesian Constitution, but it still needs further perfections, particularly on the limitation of such tripartite powers. This article uses legal research with aims to analyse and discuss theoretical and practical issues on the governmental system of Indonesia. Theoretically, the authority of state institutions in Indonesia leads to a presidential government system. In fact, in carrying out functions and authorities, state institutions do not reflect that the Indonesian system of government embraces the separation of powers existing in the presidential government system but closer to the power-sharing system. In addition, this study recommends the need for refinement and improvement efforts, so that conceptually and practice to be ideal.
\end{abstract}

KEYWORDS: Theory and Practice, Governmental System, Indonesia.

Copyright $\odot 2018$ by Author(s)

This work is licensed under a Creative Commons Attribution-ShareAlike 4.0 International License. All writings published in this journal are personal views of the authors and do not represent the views of this journal and the author's affiliated institutions.

\section{HOW TO CITE:}

Yani, Ahmad. "Sistem Pemerintahan Indonesia: Pendekatan Teori dan Praktik" (2018) 5:2 Lentera Hukum 265-276.

Submitted: February 22, 2018 Revised: March 14, 2018 Accepted: April 19, 2018 


\section{PENDAHULUAN}

Pembukaan Undang-Undang Dasar 1945 (UUD 1945) merupakan norma dasar bernegara (staatsfundamentalnorm), menggambarkan cita-cita bangsa yang di dalamnya juga terdapat pernyataan Kemerdekaan. Pembukaan UUD 1945 yang dirumuskan dan ditetapkan oleh para founding fathers menjadi sumber dan dasar bagi penyusunan berupa pasal dan ayat dalam UUD 1945. Dalam kenyataannya masih ada norma-norma dasar yang harus dituangkan dalam pasal-pasal namun belum dituangkan dalam pasal-pasal. Hal tersebut merupakan hal yang wajar mengingat pada saat persidangan Panitia Persiapan Kemerdekaan Indonesia (PPKI) mayoritas anggotanya menghendaki segera merdeka. Soekarno sebagai ketua PPKI mengatakan UUD 1945 sifatnya hanya sementara, karena disadari kurang lengkap dan kurang sempurnanya UUD 1945 bersifat sementara. ' Ketidaksempurnaan UUD 1945 juga telah diungkapkan Sri Soemantri Guru Besar Hukum Tata Negara Universitas Padjadjaran Bandung. Menurutnya, ketidaksempurnaan itu patut dipahami karena proses pembuatan UUD 1945 hanya berlangsung 45 hari dan itu pun dilakukan dalam suasana bulan puasa. Akan tetapi, hal itu tidak harus dipahami bahwa proses pembuatan dalam waktu yang cukup panjang akan menghasilkan UUD 1945 yang sempurna, sebab pada prinsipnya sebuah UUD 1945 harus selalu disesuaikan dengan perkembangan zaman. Lembaga yang berhak menyesuaikan UUD 1945 sebagai hukum tertinggi dan mengikutituntutan zaman ialah Majelis Permusyaratan Rakyat (MPR). ${ }^{2}$

MPR didesain sebagai lembaga tertinggi negara sejak awal pemebentukannya, jadi MPR tidak kalah pentingnya, selain hubungan DPR dengan Presiden. Dengan demikian, kedudukan MPR juga perlu diberdayakan, dengan diadakannya pengaturan yang lebih jelas dan tegas pengaturan tentang wewenang dan tanggung jawab antara DPR dan MPR. Berdasarkan UUD 1945, kedaulatan rakyat merupakan lembaga yang meliputi kekuatan sosial politik, utusan daerah dan golongan dilembagakan di dalam MPR. Kedaulatan berada di tangan rakyat dan dilaksanakan sepenuhnya oleh MPR. Frase "sepenuhnya" diartikan tidak terbagi dengan lembaga lain, akan tetapi banyak yang bertendensi mengambil alih kekuasaan rakyat (akibat dari penjelmaan seluruh rakyat). MPR sebagai pemegang kedaulatan rakyat berkedudukan lebih tinggi dari lembaga lainnya dan tidak membagi kedaulatannya dengan lembaga lain sehingga pengaturan tentang kedudukan dan susunan MPR, ditetapkan oleh MPR sendiri. ${ }^{3}$

1 ...Undang-Undang Dasar yang buat sekarang ini, adalah Undang-Undang Dasar Sementara. Kalau boleh saya memakai perkataan: ini adalah Undang-Undang Dasar kilat. Nanti kalau kita telah bernegara di dalam suasana yang lebih tenteram, kita tentu akan mengumpulkan kembali Majelis Perwakilan Rakyat yang dapat membuat UndangUndang Dasar yang lebih lengkap dan lebih sempurna. Tuan-tuan tentu mengerti, bahwa ini adalah sekedar Undang-Undang Dasar Sementara, Undang-Undang Dasar kilat, bahwa barangkali boleh dikatakan pula, inilah revolutie grondwet. Lihat dalam, Hadji Muhammad Yamin, Naskah Persiapan Undang-Undang Dasar 1945, Djilid Pertama, Cet Ke-2, (Jakarta: Siguntang, 1971), hlm. 410.

2 Zulkarnain Ridlwan, "Cita Demokrasi Indonesia dalam Politik Hukum Pengawasan DPR terhadap Pemerintah" hlm. 307, Jurnal Konstitusi, Volume 12, No. 2, Juni 2015.

3 Sri Soemantri menyatakan disamping adanya faktor politik yang berpengaruh, menurut sejarah pembentukan dan penetapannya UUD tersebut merupakan hasil perpaduan pandangan golongangolongan yang terdapat dalam masyarakat dan oleh karena itu dapat mempersatukan bangsa 
Dalam struktur pemerintahan Indonesia, selain eksekutif dan legislatif juga memiliki lembaga yudikatif yaitu Mahkamah Agung (MA). Sebagai lembaga peradilan, peran MA memerlukan ketegasan dalam UUD 1945. Kekuasaan Kehakiman harus diberikan ketegasan sebagai lembaga peradilan yang memiliki independensi. Mengutip pemikiran Sri Soemantri bahwa MA semestinya diberi wewenang untuk melakukan hak uji terhadap undang-undang (judicial review) sebelum lahirnya Mahkamah Konstitusi (MK). ${ }^{4}$

Dengan demikian, pembagian kekuasaan yang jelas di antara tiga cabang kekuasaan yang disebutkan dalam trias politika yaitu Eksekutif, Legislatif dan Yudikatif berdasarkan prinsip "checks and balances" sudah tertuang sejak perumusan sampai pengesahan. Akan tetapi, diperlukan langkah penyempurnaan, terutama pengaturan atas pembatasan kekuasaan dan wewenang yang jelas dari Presiden sehingga tidak ada kesewenang-wenangan. Selanjutnya, perlu ada kejelasan peran dan fungsi DPR dalam hal fungsi perundang-undangan, fungsi pengawasan kekuasaan pemerintahan dan fungsi perwakilan rakyat. Sehingga DPR dapat benar-benar melaksanakan fungsinya sebagai pengemban kedaulatan rakyat. Di samping itu, juga perlu kejelasan fungsi dan peran MPR dalam rangka memberdayakan lembaga negara berdasarkan konstitusi yang dianggap sebagai pegejewantahan kedaulatan rakyat. Masalah peningkatan wewenang lembaga kehakiman (yudikatif) juga menjadi perhatian dalam rangka menegakkan "checks and balances" antara tiga cabang kekuasaan yang sesuai dengan sistem presidensiil Indonesia.

Tidaklah berlebihan jika Harun Alrasid memberikan pemikiran bahwa di Indonesia perlunya dilakukan reformasi konstitusi dengan menetapkan UUD 1945 yang bersifat tetap, sebab selama 53 tahun Indonesia merdeka belum memiliki UUD 1945 yang bersifat tetap. UUD 1945 yang dijadikan UUD Indonesia masih bersifat sementara, tidak lengkap, dan tidak sempurna. Dengan demikian, UUD 1945 perlu diperbaiki. Kalau UUD 1945 dipandang sebagai UUD yang bersifat tetap, ketentuan di

Indonesia. Kemudian UUD 1945 sebagai konstitusi tertulis berisi: hasil perjuangan politik bangsa di waktu yang lampau, yang terlihat dari isi Pembukakaan UUD 1945. Selain itu, UUD 1945 berisi pandangan tokoh-tokoh bangsa yang hendak diwujudkan baik untuk waktu sekarang maupun untuk masa yang akan datang. Lihat dalam, Sri Soemantri Martosoewignyo, Persepsi Terhadap Prosedur dan Sistem Perubahan Konstitusi dalam Batang Tubuh Undang-Undang Dasar 1945, (Bandung: Alumni, 1979), hlm. 41-43.

4 Dalam hal ini penjelasan Sri Soemantri menjelaskan saat perumusan UUD 1945 yudicial review sebelumnya pernah ditolak. Manakala, Prof. Soepomo pada waktu menanggapi usul almarhum Mr. Mohammad Yamin, agar dalam Undang-Undang Dasar, Prof Soepomo di dalam sidang itu menolak, dengan dua alasan. Alasan yang pertama, kita masih kekurangan sarjana hukum yang memahami itu, beliau lupa bahwa Undang-Undang Dasar itu berlaku untuk jangka waktu yang panjang. Nah, sekarang ini hampir setiap kabupaten ada Fakultas Hukum. Jumlah sarjana hukum ini sudah banyak, walaupun kualitasnya masih perlu mendapat perbaikan. Lalu yang kedua, dikatakan oleh beliau Bahwa hak uji materiil itu tidak bisa dilepaskan dari teori trias politica. Dikutip dalam Mahkamah Konstitusi, Naskah Komprehensif Perubahan Undang-Undang Dasar Negara Republik Indonesia Tahun 1945 Latar Belakang, Proses, dan Hasil Pembahasan, 1999-2002; Buku I Edisi Revisi, Jakarta: Sekretariat Jenderal dan Kepaniteraan Mahkamah Konstitusi, 2010, hlm. 225. 
dalamnya yang bersifat baik perlu dipertahankan dan yang bersifat tidak baik perlu dihilangkan atau disempurnakan. ${ }^{5}$

Berdasarkan uraian di atas, tulisan ini akan menjelaskan berbagai teori dan praktiknya terhadap pelaksanaan sistem pemerintahan Indonesia. Adapun terdapat dua rumusan masalah dalam penulisan ini yaitu bagaimana secara konsepsional sebagai dasar pelaksanaan sistem presidensiil di Indonesia dan bagaimana secara praktiknya pelaksanaan sistem pemerintahan Indonesia berdasakan pendekatan UUD 1945.

Metode yang digunakan dalam penulisan ini adalah metode penelitian hukum normatif atau penelitian hukum kepustakaan. Dengan kata lain, penelitian hukum yang dilakukan dengan cara meneliti bahan pustaka atau data sekunder. ${ }^{6}$ Penelitian hukum normatif atau kepustakaan tersebut mencakup penelitian terhadap asas-asas hukum, penelitian terhadap sistematik hukum, penelitian terhadap taraf sinkronisasi vertikal dan horizontal, perbandingan hukum dan sejarah hukum. ${ }^{7}$ Dalam penelitian hukum normatif ini penulis menggunakan pendekatan perundang-undangan (statute approach). Hal ini dilakukan dengan menelaah semua undang-undang dan regulasi yang terkait dengan isu hukum yang sedang ditangani. ${ }^{8}$ Pendekatan peraturan perundang-undangan adalah pendekatan dengan menggunakan legislasi dan regulasi. ${ }^{9}$ Dengan metode ini penulis dapat menganalisis regulasi tersebut, mengidentifikasi dan menyesuaikan dengan regulasi terkait yang lainnya. Sehingga penulis dapat mengetahui kelemahan dan kekurangan peraturan yang terkait dan memperoleh jawaban tentang isu-isu antara ketentuan produk hukum dengan filosofi yang melahirkan produk hukum itu. Bahan dasar penelitian hukum normatif yakni bahan hukum primer, bahan hukum sekunder dan bahan hukum tersier atau penunjang. ${ }^{10}$

Sumber bahan hukum primer yang penulis gunakan dalam penelitian hukum normatif ini diantaranya UUD 1945 sebagai konstitusi dan peraturan perundangundangan terkait lainnya. Bahan hukum sekunder yang penulis gunakan antara lain, literatur-literatur berupa buku teks yang berkaitan dengan judul penelitian, hasil simposium/seminar, karangan ilmiah, jurnal hukum, dan teori-teori hukum. Selanjutnya bahan hukum tersier, yaitu bahan yang yang memberikan penjelasan atau yang mendukung bahan hukum primer dan bahan hukum sekunder seperti Black's Law Dictionary dan Kamus Hukum. Dalam penelitian ini prosedur pengumpulan bahan hukum yang digunakan yakni studi dokumentasi dengan mengumpulkan bahan hukum berupa penelusuran literatur hukum dan catatan untuk memuat kutipan serta informasi lainnya yang dilakukan baik secara offline dan secara online. Bahan hukum tersebut lalu didefinisikan, ditelaah dan diklasifikasikan secara sistematis agar menjadi data sekunder yang valid.

\footnotetext{
"Konstitusi Perlu Direformasi", Suara Karya, 16-6-1998.

6 Soerjono Soekanto, Sri Mamudji. Penelitian Hukum Normatif. (Jakarta: PT. Raja Grafindo Persada, 2012).hlm. 13

Ibid, hlm. 14.

Ibid, hlm. 11.

Peter Mahmud Marzuki. Penelitian Hukum, edisi revisi (Jakarta: Prenadamedia, 2005), hlm. 13.

Ibid, hlm. 38 .
} 


\section{KONSEPSI DASAR SISTEM PEMERINTAHAN}

Sri Seomantri menyatakan bahwa sistem pemerintahan adalah hubungan antara lembaga legislatif dan eksekutif terdapat perbedaan yang jelas antara sistem pemerintahan presidensiil dan parlementer. Masing-masing memiliki ciri-ciri sebagaimana diungkapkannya dalam kutipan berikut. Pertama, masalah sistem pemerintahan yang dianut oleh UUD 1945. Memang di kalangan saat ini ada dua sampai tiga pendapat. Yang pertama, mengatakan bahwa yang berlaku sekarang ini sistem pemerintahan presidensiil. Kedua, mengatakan itu bukan sistem presidensiil, bahkan ini dikatakan ada semacam campuran. Ketiga ini mencari solusi, seperti yang dikemukan oleh almarhum Prof. Padmo Wahyono yang mengatakan sistem MPR. ${ }^{\text {ll }}$

Indonesia merupakan negara dengan sistem pemerintahan Presidensial. Hal ini didasarkan pada kesepakatan pendiri bangsa (founding fathers) dalam sidang Badan Penyelidik Usaha Persiapan Kemerdekaan (BPUPK) pada 29 Mei- 1 Juni dan 10-17 Juli 1945. ${ }^{12}$ Sistem pemerintahan presidensiil itu mempunyai ciri-ciri yang khas sebagaimana dianut di Amerika Serikat. Pertama, sistem itu didasarkan atas asas pemisahan kekuasaan. Seorang pakar ilmu politik Amerika Serikat menyatakan it is based upon the separation of power principle. Yang kedua, tidak ada pertanggungjawaban bersama antara Presiden sebagai pemimpin eksekutif dengan para menteri. Para menteri itu sepenuhnya bertanggung jawab kepada Presiden. Yang ketiga, Presiden tidak dapat membubarkan DPR dan yang keempat, presiden itu dipilih oleh Dewan Pemilih. Jadi ini sistem pemerintahan presidensiil sebagaimana berlaku di Amerika Serikat lalu bagaimana dengan sistem pemerintahan presidensiil di Indonesia?

Adapun maksud sistem pemerintahan parlementer adalah didasarkan atas asas defusion of powers yang antara lain presidensiil separation of powers dan parlementer defusion of powers. Pada sistem parlementer, baik pemerintah maupun parlemen itu dapat saling membubarkan. Pemerintah dapat dibubarkan oleh parlemen apabila tidak mendapat dukungan mayoritas dari anggota parlemen, parlemen pun dapat dibubarkan oleh pemerintah melalui kepala negara apabila dianggap tidak mencerminkan lagi aspirasi rakyatnya. Dan yang keempat, sistem parlementer kepala pemerintahan adalah Perdana Menteri, sebagai kepala eksekutif yang ditetapkan oleh kepala negara, apakah itu presiden, atau raja. ${ }^{13}$ Sistem parlementer menjadi bagian dari sistem pemerintahan yang digunakan oleh Indonesia sejak tahun 1949-1959 dengan konstitusi berbeda, yaitu Konstitusi RIS 1949 dan UUDS 1950.

Dari rangkaian perjalanan sistem pemerintahan Indonesia, apabila dikatakan sistem pemerintahan presidensiil, Indonesia tidak menganut asas pemisahan kekuasaan. Begitupun, apabila dikatakan sistem parlementer, tidak terdapat

Il Sri M Soemantri, Sri 1992, Bunga Rampai Hukum Tata Negara Indonesia, (Bandung: Alumni 1992), hlm. 90.

12 Saldi Isra, Pergeseran Fungsi Legislasi, Menguatnya Model Legislasi Parlementer dalam Sistem Presidensial Indonesia, Jakarta: Rajawali Pers, 2010, hlm. 4 dikutip di M. Yasin al-arif "Anomali Sistem Pemerintahan Presidensial Pasca Amandemen UUD 1945” hal. 239. Jurnal Hukum IUS QUIA IUSTUM No.2 Vol.22 April 2015:238-254.

13 Ibid. Lihat Juga Dalam David Marsh dan Gerry Stoker, Teori Dan Metode Dalam Ilmu Politik (Terj.), (Bandung: Penerbit Nusa Media, 2010), hlm. 240. 
mekanisme pembagian kekuasaan yang jelas, bahkan cenderung mengadopsi kedua sistem. Sistem pembagian kekuasaan yang dianut itu tidak terpisah antara lembaga negara yang satu dengan lembaga negara lainnya. Sehubungan dengan hal tersebut, Ismail Suny ${ }^{14}$ berpendapat bahwa sistem pemerintahan adalah suatu sistem tertentu yang menjelaskan bagaimana hubungan antara alat-alat kelengkapan negara yang tertinggi di suatu negara. Berkaitan dengan sistem pemerintahan, pada umumnya dibedakan kedalam dua sistem utama, yaitu sistem presidensiil dan parlementer, diluar kedua sistem tersebut merupakan sistem campuran atau kuasa parlementer atau kuasa presidensiil, ada juga menyebut sistem referendum.

Sebenarnya konsep sistem pemerintahan tersebut tidak bisa dilepaskan dari pemikiran politik Montesqieu yang menawarkan gagasan pemisahan kekuasaan serta Jhon Locke yang menawarkan gagasan pembagian kekuasaan. Inti dari konsep Montesqieu ini adalah agar tidak terjadi pemusatan kekuasaan dan terbentuknya kekuasaan mutlak yang sewenang-wenang, maka kekuasaan perlu dipisahkan. Dalam hal ini, Montesqieu memisahkan kekuasaan negara menjadi tiga bentuk kekuasaan yaitu, kekuasaan legislatif, eksekutif dan yudikatif. Walaupun gagasan ini bukan gagasan baru karena J. J. Rousseau maupun John Locke telah membahasnya secara mendalam. Hanya dalam beberapa aspek terdapat perbedaan pemahaman atau penekanan mengenai ketiga lembaga kekuasaan itu di antara mereka. ${ }^{15}$

Mengapa gagasan pemisahan itu muncul? Gagasan apa yang ada di balik pemisahan kekuasaan? Pertama adalah gagasan bahwa demi terjaminnya kebebasan politik rakyat (political liberty) perlu ada pemisahan kekuasaan negara. Kebebasan merupakan hal penting dalam pemikiran Montesqieu. Gagasan keharusan adanya jaminan kebebasan inilah diantaranya yang menyebabkan Montesqieu merumuskan konsep perlunya pembatasan kekuasaan. Menurut Montesqieu kebebasan politik sulit dijaga atau dipertahankan bila kekuasaan negara tersentralisasi atau dimonopoli oleh seorang penguasa atau lembaga politik tertentu. Kekuasaan negara menurutnya perlu dibagi-bagi. Inilah yang kemudian dikenal sebagai gagasan pemisahan kekuasaan negara (separation of power).

Montesqieu seperti yang diutarakan Deliar Noer, ${ }^{16}$ apabila kekuasaan legislatif dan eksekutif disatukan pada tangan yang sama ataupun pada badan penguasapenguasa yang sama, tidak mungkin terdapat kemerdekaan, juga tidak akan bisa ditegakkan kemerdekaan itu bila kekuasaan mengadili tidak dipisahkan dari kekuasaan legislatif dan eksekutif. Apabila kekuasaan mengadili disatukan dengan dua kekuasaan itu, kemerdekaan rakyat akan terancam karena hakim akan menjadi orang yang membuat hukum. Maka bila kekuasaan mengadili digabungkan pada kekuasaan eksekutif, hakim itu akan bersikap dan bertindak dengan kekerasan dan penindasan.

Berdasarkan uraian tersebut, maka sistem pemerintahan adalah hubungan antara penyelengara negara atau lembaga-lembaga yang melaksanakan kegiatan pemerintah

\footnotetext{
14 Ismail Sunny, Mekanisme Demokrasi Pancasila, cet.vi, (Jakarta: Aksara Baru, 1987), hlm. 9-10.

15 Ibid.

16 Deliar Noer, Pemikiran Politik Di Negeri Barat, (Bandung: Mizan, 1998), hlm. 136.
} 
dalam arti luas dalam suatu tatanan untuk mencapai tujuan negara dengan adanya pemisahan kekuasaan yang dapat menjamin kehidupan bernegara. Dalam arti sempit, hubungan tersebut akan dikaitkan antara lembaga eksekutif dan lembaga legislatif yang kemudian dituangkan dalam naskah konstitusi.

Di sisi lain, Bambang dalam artikelnya menyampaikan beberapa hal yang harus disebut secara limitatif dalam konstitusi ialah public authority hanya dapat dilegitimasi sesuai dengan ketentuan konstitusi; pelaksanaan kedaulatan rakyat dilakukan dengan menggunakan prinsip universal and equal suffrage dan pemilihan eksekutif secara demokratis (popular sovereignty and democratic government); pemisahan kekuasaan serta pembatasan kewenangan yang diberikannya; adanya kebebasan kekuasaan kehakiman yang mampu menegakkan rule of law dan melaksanakan law enforcement terhadap constitutional order, sistem konstitusi mempunyai sistem yang bisa mengontrol lembaga kepolisian dan militer untuk mewujudkan hukum yang demokratis dan menghormati hak-hak rakyat; dan negara memberikan jaminan terhadap hak-hak asasi manusia. ${ }^{17}$

Untuk menghidari adanya penafsiran sepihak yang dapat dilakukan oleh salah satu lembaga negara, Yusril Ihza Mahendra dalam pidato pengukuhannya sebagai Guru Besar Hukum Tata Negara Universitas Indonesia pada 24 April 1998 mengemukakan bahwa penafsiran terhadap konstitusi bukanlah sesuatu yang mutlak. Kalimat yang tercantum dalam Penjelasan UUD 1945 telah mengingatkan semua pihak agar jangan memutlakkan penafsirannya terhadap UUD 1945 serta menganggap penafsiran itu sebagai kebenaran final yang tidak dapat diubah atau diperbarui. ${ }^{18}$ Bahkan Adnan Buyung Nasution, menegaskan bahwa UUD 1945 yang hanya terdiri atas 37 pasal itu terlalu sederhana. Kesederhanaan ini dimaksudkan supaya fleksibel, mudah diubah, dan pelaksanaannya bisa diatur lebih lanjut dengan undang-undang. Hal itu berbahaya karena dapat memberikan peluang kepada siapa pun yang berkuasa untuk bersekongkol dengan DPR membuat undang-undang yang menguntungkan kekuasaan. ${ }^{19}$

Dengan demikian, secara realitas politik maupun secara konseptual kewenangan lembaga negara selalu terkooptasi oleh satu lembaga politik tertentu yang menyebabkan tidak mampu menjalankan fungsi dan kewenangannya yang mencerminkan sistem check and balances. Seperti halnya kewenangan DPR yang selalu lemah dalam menjalankan kewenangan pembuatan undang-undang, bahkan terdapat kecenderungan tidak mencerminkan bahwa sistem pemerintahan Indonesia menganut pemisahan kekuasaan akan tetapi lebih dekat pada sistem pembagian kekuasaan. Secara konseptual maka Indonesia dalam sistem kenegaraannya lazim digunakan oleh negara dengan sistem pemerintahan parlementer bukan presidensiil.

17 Bambang Wijojanto, "Reformasi Konstitusi: Sebuah Keniscayaan" Detak, No. 014 Tahun ke-1, 13-19 Oktober 1998.

18 "Perlu Pendekatan Baru dalam Pemikiran Konstitusi Kenegaraan", Republika, 15-10-1998.

19 “UUD 1945 Hanya Bisa Diubah dengan Amandemen”, Detak, No. 014 Tahun ke-1, 13-19 Oktober 1998. 


\section{PRAKTIK SISTEM PEMERINTAHAN BERDASARKAN KONSTITUSI} Meskipun telah merdeka selama hampir 73 tahun negara Indonesia, akan tetapi dalam menyelenggarakan sistem pemerintahan seakan masih dalam tahap mencari format ideal yang sesuai dengan nilai-nilai masyarakat Indonesia. PraktIk ketatanegaraan yang terjadi kurang mencerminkan jiwa dan semangat UUD 1945. Dengan rumusan singkat dan aturan-aturan yang hanya bersifat pokok dalam UUD 1945, semula diharapkan akan mempermudah praktik penyelenggaraan pemerintahan negara melalui pengaturan undang-undang. Namun, pada sisi lain ternyata mudah disimpangi sesuai selera penyelenggara negara sehingga terjadilah praktik korupsi, kolusi, dan nepotisme. Dampaknya telah menyengsarakan rakyat dan merusak etika, moral dan semangat para penyelenggara negara dan seluruh rakyat Indonesia.

Salah satu yang menilai perluanya perubahan UUD 1945 adalah hasil penelitian yang dilaksanakan Lembaga Ilmu Penelitian Indonesia (LIPI) di tahun 1999 menyimpulkan perlunya perubahan terhadap UUD 1945. LIPI menganggap adanya cacat bawaan dalam UUD 1945, seperti minimnya pengaturan terhadap muatan Pasal menyangkut HAM, tiadanya mekanisme check and balance, lemahnya sistem distribution of power antara lembaga eksekutif, legislatif, dan yudikatif. Bahkan UUD 1945 menempatkan eksekutif sebagai pengendali utama jalannya pemerintahan atau executive heavy dan UUD 1945 selama diberlakukan oleh dua pemerintahan sebelumnya (Orde Lama dan Orde Baru) tidak pernah melahirkan pemerintahan yang demokratis. ${ }^{20}$

Berbeda halnya dengan UUDS 1950. Kedaulatan rakyat itu dilakukan oleh pemerintah bersama-sama dengan DPR, yang produknya itu adalah undang-undang. Dengan demikian, di dalam sistem UUDS 1950, undang-undang tidak dapat diganggu gugat. Tidak dapat undang-undang itu diuji secara materiil. UUDS 1950 merupakan undang-undang dasar transisi yang dimaksudkan untuk kembali pada bentuk negara kesatuan. Sehubungan dengan itu dalam UUDS 1950 terdapat ketentuan tentang Konstituante sebagai lembaga yang dibentuk atas dasar Pemilihan Umum (Pemilu) dan bertugas untuk membentuk undang-undang dasar yang baru.

Berbeda ketika praktik sistem pemerintahan berdasarkan UUD 1945. Hasil perubahan mendasar antara lain perubahan Pasal 1 Ayat (2) UUD 1945; sebelum perubahan menetapkan, "Kedaulatan berada di tangan rakyat dan dilakukan sepenuhnya oleh MPR" menjadi rumusan baru yaitu "Kedaulatan adalah di tangan rakyat dan dilaksanakan menurut Undang-Undang Dasar". Perubahan ini menegaskan asas kedaulatan rakyat, akan tetapi sekaligus juga meneguhkan asas negara yang konstitusional, demokratis dan berdasarkan hukum. UUD 1945 sebagai pencerminan kehendak rakyat yang tertinggi menetapkan berlakunya kedaulatan rakyat yang pelaksanaannya diserahkan kepada lembaga-lembaga negara sesuai prinsip permusyawaratan/perwakilan dengan penerapan mekanisme cheks and balances.

MPR yang ditetapkan terdiri atas DPR dan DPD yang masing-masing dipilih oleh rakyat melalui pemilu. Selain itu, Presiden dan Wakil Presiden dipilih sebagai satu

20 Amandemen UUD 1945 dan Permasalahan, Penerbitan PMB-LIPI No. 15 Tahun 1999. 
pasangan secara langsung oleh rakyat dan dicalonkan oleh partai politik atau gabungan partai politik peserta pemilu. Kemudian Kekuasaan Kehakiman dilakukan oleh Mahkamah Agung (MA) dan badan peradilan dibawahnya dan oleh Mahkamah Konstitusi (MK). Dengan demikian, secara struktural sistem pemerintahan sangat berbeda dengan UUD 1945 sebelum perubahan. Banyak perbaikan dan penegasan fungsi serta kewenangan dari lembaga tertentu, perubahan UUD 1945 juga melahirkan lembaga negara baru yang secara kelembagaan tergolong lembaga legislatif yaitu DPD dan MK.

Posisi kedudukan MPR yang terdiri atas DPR dan DPD secara konseptual maupun struktural bukan lagi sebagai lembaga tertinggi negara setelah kewenangan dan komposisi keanggotaan MPR mengalami perubahan. MPR seperti sebuah forum, forum antara DPR dan DPD. Ketika DPD dan DPR itu berkumpul itu sebenarnya ada sebuah institusi yang berbentuk secara insidentil. Atas dasar itulah, kemudian bisa mengeluarkan suatu produk hukum, karena jika tidak akhirnya tidak ada produk hukum. Meskipun masih mempertahankan eksistensi MPR. Tetapi untuk memahami MPR itu bukan sebuah lembaga yang punya otoritas seperti masa yang lalu, untuk itulah kalau penulis katakan ini adalah sebuah badan kenegaraan yang sifatnya sangat insidentil. Dengan demikian, perubahan MPR sejak perumusan, perubahan dan ke depan keberadaan MPR memerlukan pemikiran lebih modern dalam konsep yang akan datang.

Meskipun mengalami berbagai perubahan, untuk mencapai suatu tujuan negara modern secara konstitusi masih memerlukan berbagai perbaikan kembali untuk mencapai suatu kesempurnaan sistem pemerintahan baik secara konseptual maupun secara praktik ketatanegaraan. Bahkan Adnan Buyung Nasution mensistematisasikan kelemahan-kelemahan tersebut menjadi dua jenis, yaitu kelemahan konseptual dan kelemahan dari segi konstruksi hukumnya. Kelemahan dari segi konseptual diantaranya adalah konsep negara yang dipersepsikan oleh UUD 1945, yaitu konsep negara integralistik sementara kelemahan dari segi konstruksi hukumnya adalah kesederhanaan UUD 1945. Dengan adanya penyederhanaan ini, pelaksanaan dari UUD 1945 diatur lebih lanjut dengan undang-undang. Kondisi ini membuka peluang akan terjadinya penyelewengan-penyelewengan oleh pembuat undang-undang, sebagaimana yang terjadi selama pemerintahan Orde Baru. ${ }^{21}$

Sejalan dengan pemikiran tersebut, perubahan UUD 1945 yang telah menempatkan DPR sebagai lembaga pembuat undang-undang, secara konsepsional sangatlah ideal, karena memang lembaga perwakilan merupakan lembaga legislatif. Hal ini berlaku tidak hanya dalam sistem pemerintahan presidensiil, namun juga pada sistem pemerintahan parlementer. Akan tetapi, pada level pengajuan undang-undang, Presiden diberikan haknya untuk bisa mengusulkan suatu rancangan undang-undang. Selain itu saat pembahasan, presiden dan DPR harus melalui mekanisme pembahasan dan persetujuan bersama untuk suatu rancangan undang-undang. Kemudian dalam

21 Adnan Buyung Nasution, Aspirasi Pemerintahan Konstitusional Di Indonesia,(Jakarta: Graffiti Press, 1995), hlm. 125. 
mekanisme pembahasan, persetujuan sampai penetapan harus melalui mekanisme yang kemudian diatur dalam undang-undang. Dengan demikian, hubungan antara DPR dan presiden tidak menunjukkan adanya check and balances, yang terjadi adalah pembagian kekuasaan dan kewenangan presiden dapat dipastikan lebih besar daripada DPR.

Manakala tidak terdapat persetujuan bersama, presiden dalam UUD 1945 masih memiliki hak istimewanya dalam Pasal 22 ayat (1) UUD 1945 disebutkan "dalam hal ihwal kegentingan yang memaksa, Presiden berhak menetapkan peraturan pemerintah pengganti undang-undang", 22 penatapan Peraturan Pemerintah Pengganti Undangundang (Perpu) yang dilakukan oleh presiden juga tertulis dalam Pasal 1 angka 4 Undang-Undang Nomor 12 Tahun 2011 tentang Pembentukan Peraturan PerundangUndangan yang disebutkan "Perpu adalah peraturan perundang-undangan yang ditetapkan oleh presiden dalam hal ihwal kegentingan yang memaksa" ${ }^{23}$ namun dalam praktiknya Perpu yang diajukan oleh presiden untuk dimintai persetujuan DPR selalu dalam kondisi normal tidak ada kegentingan yang memaksa. Seperti halnya Perpu tentang Organisasi Kemasyarakatan (Ormas) yang kemudian disetujui oleh DPR menjadi undang-undang.

Selain MPR, kewenangan lembaga Yudikatif, harus diakui dengan adanya MK secara kelembagaan suatu kemajuan bagi kelangsungan hukum bangsa Indonesia. Dibukanya ruang judicial review atas suatu undang-undang apakah bertentangan dengan UUD 1945. Selain menyangkut keadilan, lembaga yudikatif yang terdiri dari MA dan MK ini, semakin membuka ruang bagi masyarakat Indonesia untuk menyampaikan ketidakadilan, baik secara peradilan umum maupun peradilan konstitusi. Akan tetapi, yang harus dipahami, MK adalah negatif legislator yaitu hanya berfungsi sebagai penguji undang-undang atas Undang-Undang Dasar. Maka MK, dalam putusannya hanya mengabulkan atau tidak mengabulkan atas uji materiil suatu hasil undangundang yang sudah disetujui bersama oleh presiden dan DPR. Dalam perkembangannya, ketentuan tersebut ditafsirkan berbeda oleh hakim-hakim MK, sehingga terjadi pergeseran kewenangan MK, dari negatif legislator ke positif legislator. Dalam konteks ketatanegaraan, kewenangan khusus MK merupakan pengejewantahan judicial control dalam kerangka check and balances di antara cabang-cabang kekuasaan negara. Terlalu jauhnya peran MK yang menjelma seperti DPR sebagai lembaga yang memiliki kewenangan dalam pembuat undang-undang. MK terkadang overlapping dalam menjalankan kewenangannya hingga mengeluarkan norma-norma baru dari produk yang dikeluarkan.

\section{KESIMPULAN}

Berdasarkan pembahasan di atas, dapat disimpulkan bahwa secara realitas politik maupun secara konseptual kewenangan lembaga-lembaga negara selalu terkooptasi

22 Lihat Undang-Undang Dasar 1945 setelah Perubahan.

23 Lihat dalam Pasal 1 angka 4 Undang-Undang Nomor 12 Tahun 2011 tentang Pembentukan Peraturan Perundang-Undangan. 
oleh satu lembaga politik tertentu. Hal tersebut yang menyebabkan tidak mampu menjalankan fungsi dan kewenangannya yang mencerminkan sistem check and balances. Sehingga secara konseptual kewenangan lembaga-lembaga negara dalam sistem pemerintahan presidensiil diperlukan kembali upaya penyempurnaan, agar secara konsepsional dapat berjalan secara ideal.

Kemudian secara praktik dalam menjalankan fungsi dan kewenangan, lembaga negara tidak mencerminkan bahwa sistem pemerintahan Indonesia menganut pemisahan kekuasaan akan tetapi lebih dekat pada sistem pembagian kekuasaan. Secara kenegaraan sistem yang demikian lazim digunakan oleh negara dengan sistem pemerintahan yang bukan presidensiil seperti yang digunakan di Indonesia.

\section{DAFTAR PUSTAKA}

Amandemen UUD 1945 dan Permasalahan, Penerbitan PMB-LIPI No. 15 Tahun 1999. "Konstitusi Perlu Direformasi", Suara Karya, 16-6-1998.

Isra, Saldi, Pergeseran Fungsi Legislasi, Menguatnya Model Legislasi Parlementer dalam Sistem Presidensial Indonesia, (Jakarta: Rajawali Pers, 2010). Dalam M. Yasin al-arif "Anomali Sistem Pemerintahan Presidensial Pasca Amandemen UUD 1945". Jurnal Hukum IUS QUIA IUSTUM No.2 Vol.22 April 2015:238-254.

Marsh, David \& Dan Gerry Stoker, Teori Dan Metode Dalam Ilmu Politik (Terj.), (Bandung: Penerbit Nusa Media, 2010).

Mahkamah Konstitusi, "Naskah Komprehensif Perubahan Undang-Undang Dasar Negara Republik Indonesia Tahun 1945 Latar Belakang, Proses, dan Hasil Pembahasan, 1999-2002", Buku I Edisi Revisi, (Jakarta: Sekretariat Jenderal dan Kepaniteraan Mahkamah Konstitusi, 2010).

Martosoewignyo, Sri Soemantri. Bunga Rampai Hukum Tata Negara Indonesia, (Bandung: Alumni, 1992).

Martosoewignyo, Sri Soemantri. Persepsi Terhadap Prosedur dan Sistem Perubahan Konstitusi dalam Batang Tubuh Undang-Undang Dasar 1945, (Bandung: Alumni, 1979).

Marzuki, Peter Mahmud. Penelitian Hukum, edisi revisi (Jakarta: Prenadamedia, 2005).

Noer, Deliner. Pemikiran Politik Di Negeri Barat, (Bandung: Mizan, 1998).

Nasution, Adnan Buyung. Aspirasi Pemerintahan Konstitusional Di Indonesia (Jakarta: Graffiti Press, 1995).

"Perlu Pendekatan Baru dalam Pemikiran Konstitusi Kenegaraan", Republika, 15-10-1998.

Ridlwan, Zulkarnain, "Cita Demokrasi Indonesia dalam Politik Hukum Pengawasan DPR terhadap Pemerintah", Jurnal Konstitusi, Volume 12, No. 2, Juni 2015.

Soekanto, Soerjono \& Sri Mamudji. Penelitian Hukum Normatif. (Jakarta: PT. Raja Grafindo Persada, 2012).

Sunny, Ismail. Mekanisme Demokrasi Pancasila, cet.vi (Jakarta: Aksara Baru, 1987).

Undang-Undang Dasar Negara Republik Indonesia Tahun 1945. 
Undang-Undang Nomor 12 Tahun 2011 tentang Pembentukan Peraturan PerundangUndangan.

"UUD 1945 Hanya Bisa Diubah dengan Amandemen", Detak, No. 014 Tahun ke-1, 13-19 Oktober 1998.

Wijojanto, Bambang. "Reformasi Konstitusi: Sebuah Keniscayaan” Detak, No. 014 Tahun ke1, 13-19 Oktober 1998.

Yamin, Hadji Muhammad. Naskah Persiapan Undang-Undang Dasar 1945, Djilid Pertama, Cet Ke-2, (Jakarta: Siguntang, 1971). 